\title{
John Knauss: 50 Years of Service to Oceanography
}

Margaret Leinen

National Science Foundation - Arlington, Virginia LISA

A 11 of those whose lives and careers have been touched by John Knauss' leadership in marine science, his vision of integrated and multidisciplinary approaches to marine problems, and his statesman-like dignity and humanity join me in congratulating him on 50 years of distinguished contributions to oceanography. We are delighted that Oceanograplyy has taken this opportunity to reflect on the many ways in which John has led our field and in which he has served as an example for our own careers. In my remarks I would like to reflect on some of the wonderful stories associated with this legend of oceanography.

John's introduction to oceanography came during World War II. He was one of a group of servicemen who were assigned meteorological duties that contributed to weather prediction in support of the maritime war effort. He became interested in oceanography and its relation to weather and climate as a result of this assignment. After the war he completed his B.S. at the Massachusetts Institute of Technology in 1946 and an M.S. in 1949 at the University of Michigan.

Oceanography was a young field that had gained importance during the war. Few were formally trained in the discipline. In fact, Scripps Institution of Oceanography awarded the only oceanography degrees in the country at the time. So it was not unusual that Knauss moved directly from his M.S. degree to the Office of Naval Research (ONR). He spent about two years there as a program officer during 1950 and 1951 working in the program that Roger Revelle had created at ONR. It was also no surprise that he went to Scripps for his Ph.D. in 1951 and worked with Revelle. Knauss told me that "I didn't know much in those days, but having watched research a bit from my post in ONR I knew that I needed some time to fumble around on my own at my own pace. Roger was director and too busy to worry about me; hence he was ideal."

\section{The Scripps years}

An integrated approach to oceanography including all disciplines was the hallmark of graduate education at Scripps under Sverdrup, during the late 1940s (Inman, 2000). This set the stage for John Knauss' commitment to a multidisciplinary core education for students in oceanography that has been discussed in more detail in this volume by Farrington (2001). He and others trained at Scripps at this time (e.g. Wayne Burt, Dale Liepper, Don Pritchard) served as "apostles" taking this approach to other emerging oceanographic institutions (e.g. Oregon State University, Texas A\&M University, Johns Hopkins).

Roger Revelle and John Knauss enjoyed a lifelong friendship. Before he died, Roger told several of us that John had always wanted to be a playwright. Roger provided the script of a musical play called "Endless Holiday" that Knauss wrote while a graduate student at Scripps. The musical gives some flavor of the graduate student and research life of the time. Some things never change: in the third scene a Scripps official is trying to get clearances and approvals from a long list of entities for a cruise. As he moves around the stage he trails red tape behind him. The tape is on a spool, so that no matter where he goes he leaves a trail of red tape behind him. But other characteristics of oceanography are quite different: there were no female graduate students or faculty in the play, only wives left on the beach.

During the time that Knauss was a graduate student, he returned to ONR on a two year recall in January of 1954 to lead the physical oceanography part of the early geophysics branch (under Gordon Lill) which was in the earth sciences division (under John Adkins).

Knauss' Ph.D. thesis focused on the Equatorial Undercurrent in the Pacific, or Cromwell Current. He had originally planned to do the thesis on the Equatorial Countercurrent and the thesis was nearly complete when he made his first measurements of the Equatorial Undercurrent. Knauss says that when he came back from sea, "Revelle urged me to postpone the Countercurrent; why not be known for doing the work on the Undercurrent as your Ph.D. dissertation? And, of course, he was right." By the time he completed his Ph.D. in 1959, he had twice published studies of this 
important feature of Pacific circulation in Nature. He extended this interest to equatorial circulation in the Indian Ocean through The International Indian Ocean Expedition, and, after moving to the University of Rhode Island (URI) as the founding dean of the new Graduate School of Oceanography, brought Jim Baker to URI as a post-doc. Neither could know that they would succeed each other as the top administrators of the nation's marine and atmospheric science agency, the National Oceanic and Atmospheric Administration (NOAA). Knauss' field studies kicked off a long legacy of tropical circulation experiments, field studies and discovery. That legacy is described in more detail in this issue by Weisberg (2001).

\section{The Rhode Island years}

On New Year's Day of 1959 the Chief of Naval Operations, Admiral Arleigh Burke, distributed a report authored by Gordon Lill, Arthur Maxwell and Feenan Jennings of ONR, The Next Ten Years in Oceanography (known as TENOC; Lill et al., 1959). The report called for an expanded commitment to basic oceanographic research related to Navy responsibilities for defense. A keystone of the report was the need for more oceanographers. The authors argued that investment in academic institutions was necessary to generate this new talent and ONR responded by block grants to several universities, including the University of Rhode Island, to establish academic oceanography programs.

Fred Saalfeld of ONR points out that at that time the Narragansett Bay Marine Laboratory, led by Charles Fish, was already involved in oceanographic research. About $45 \%$ of the program, which at the time amounted to about $\$ 50,000$ annually, was funded by Navy (Saalfeld, 2001). The Rhode Island program was focused on estuarine oceanography, sediment studies, acoustics and biology and had 7 faculty, 5 research associates (most of whom later became faculty) and 17 students. Then president of URI, Dr. Francis Horn, had met Harry Hess in South America and after lively conversations had been convinced that the university should invest in oceanography. After URI was identified by ONR as one of the TENOC institutions, Horn's inquiries with several nationally-known oceanographers led him to John Knauss as a leader for the new academic unit. Although barely out of graduate school, Knauss had strong connections with the Office of Naval Research and could immediately link the new oceanography program with Navy research interests. In 1961 the Graduate School of Oceanography (GSO) was founded with Knauss at the helm.

John felt strongly that he needed to have a research vessel in place at URI before he came. He worked with the University to obtain a retired World War II Army

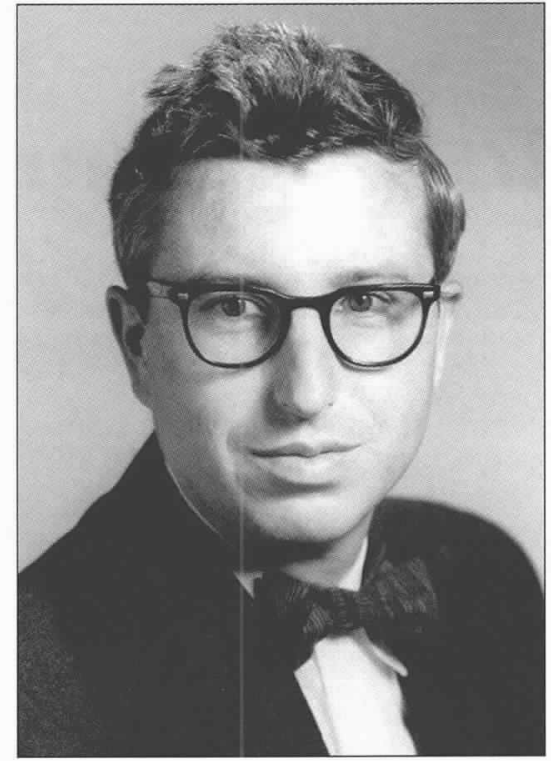

John Knauss, 1960.

machine shop vessel from surplus, which became the research vessel, Trident. As Bob Duce tells in this issue, John packed his household in containers on the ship and moved to Rhode Island (Duce, 2001). In 1961 the campus consisted of a few wooden buildings that housed the Narragansett Bay Marine Laboratory of the University.

But the times were fertile for science: in 1959 the nation was still in shock over the launch of Sputnik. As Knauss pointed out in this journal "Congress surged ahead with projects that promoted ocean science" (Knauss, 1990). In typically modest fashion, Knauss did not mention that he was a member of the cabinet-level National Oceanographic Council, that provided advice and recommendations on much of that legislation (Miloy, 1983).

Over the next 25 years Knauss led GSO to be a major oceanographic institution. When he retired in 1987 as dean it had 41 faculty, 73 professional staff, 169 students, 12 buildings, and the ocean-going research vessel Endeavor. URI/GSO had become one of the original Sea Grant college programs, accounted for $12 \%$ of the NSF ocean science funding, and had carved out a leadership role in a number of areas of oceanographic research.

\section{Sea Grant}

While a newly minted Dean of Oceanography, Knauss had a pivotal role in shaping the Sea Grant program of NOAA. A few years ago I sat with John and then Senator Claiborne Pell at the Senator's home in Rhode Island as the two of them discussed the development of Sea Grant. Athelstan Spilhaus, dean at University of Minnesota and head of the National 
Academy of Science Committee on Oceanography, had been discussing the idea of "sea-grant colleges", analogous to land grant colleges, and had proposed this idea at the 1963 annual meeting of the American Fisheries Society. A GSO faculty member who attended the meeting, Saul Saila, wrote to Spilhaus and expressed enthusiasm for the idea. Spilhaus then discussed the idea with John and with the president of URI, Francis Horn in an exchange of several letters. John and Fran Horn liked the idea and offered to convene a national conference on the concept of a Sea Grant University. Around this time, John was working at the lab on a Saturday when the junior Senator from Rhode Island, Claiborne Pell, knocked on the door of his office. Senator Pell had his son, Toby, in tow and was looking for someone to tell him what was happening in oceanography at the University. It seems that young Toby, who would have been about 12 at the time, was interested in oceanography and the Senator took this opportunity to make an informal visit to the campus. During that afternoon conversation, John talked about the concept of a marine equivalent to the land-grant system to capitalize on university-based research to assist in economic uses of the sea.

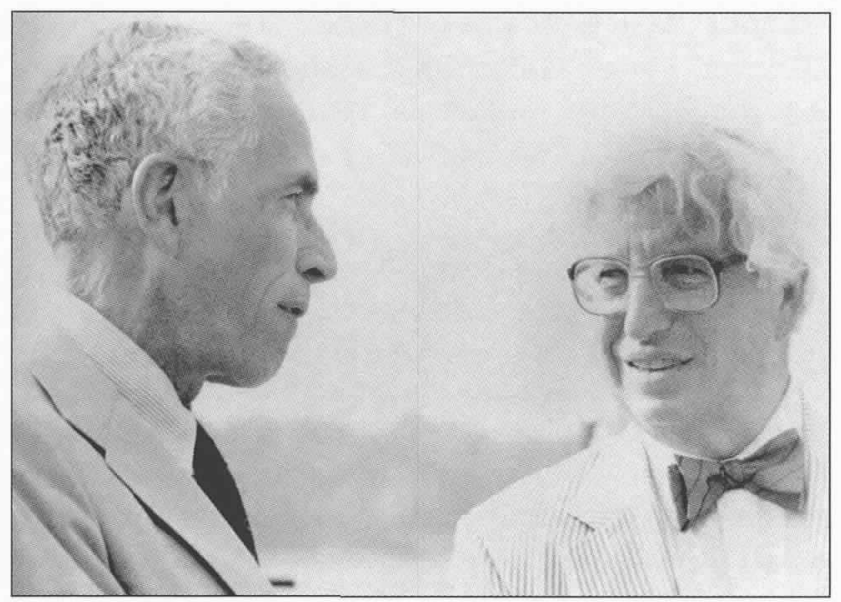

Senator Claiborne Pell and John Knauss, date unknown.

Senator Pell explained to me that he had recently visited Japan, where he saw coastal areas in which there were submerged lands staked out and reserved for specific towns for economic development. He was interested in the possibility of an analog to the land grant model in which submerged lands would be granted to universities for research. Knauss explained the need for a boundary-less and more integrated approach that would avoid the legal entanglements of submerged land ownership and provide opportunities for study of a wide range of coastal and coastal ocean problems of importance to states. Knauss saw the entire scope of problems of importance to the economies of coastal states-recreation, marine transportation, fisheries, coastal policy and legal issues, geologic resources, marine technology-and argued that they, too, should be part of the intellectual scope of a sea grant concept.

Knauss began to work with Spilhaus to plan the national conference; Spilhaus began a vigorous letterwriting campaign and set of lectures to inform a wide variety of constituencies about the concept (Miloy, 1983). In the meantime Senator Pell worked on the idea together with with Knauss, Spilhaus, and other leaders in oceanography to craft the 1965 legislation, the National Sea Grant College and Program Act (S.2439), which placed the Sea Grant Colleges in the National Science Foundation (NSF) by amendment of the NSF Act of 1950. The legislation was introduced even before the national conference was held in 1965. The conference had 224 attendees from 30 states (Difford, 1965). As a result of the conference, Knauss became chair of the National Committee on SeaGrant Colleges that was designed to "promote the legislation and ensure that universities would help shape the Sea Grant legislation" (Miloy, 1983). In February 1966, Knauss circulated a draft statement "What is a Sea Grant College?" to the committee for comment and revision. This document became the basis for the description of the program. Miloy (1983) gives a wonderful description of the difficult job of shepherding the bill through Congress, where no less than 10 bills had been introduced to amend the NSF act to create Sea Grant programs. Eventually in May of 1966 Pell scheduled hearings on his bill. The first day the subcommittee met at the University of Rhode Island, the first time a senatorial hearing had been held at a university. The final bill, P.L. 89-688, the National Sea Grant College Program and Act, was signed by President Johnson on October 15, 1966. In recognition of John's leadership role in the development of Sea Grant, the flagship program of Washington DC internships was named for him in 1979, the Dean John A. Knauss Marine Policy Fellowships.

\section{Stratton Commission}

During the mid-1960s the expansion of economic activity in the coastal zone and coastal ocean and concerns for the competitiveness of U.S. science came together. The National Academy of Science Committee on Oceanography and the Intergovernmental Committee on Oceanography had highlighted the need for national policy on issues like fisheries, coastal zone development and management and oceanographic science (Knauss, 1990). After several years with a lack of consensus, Congress authorized the Commission on Marine Science, Engineering and Resources in 1966 to ensure "full and wise use of the marine environment" and to recommend appropriate governmental structure under the leadership of Julius Stratton, chairman of the 


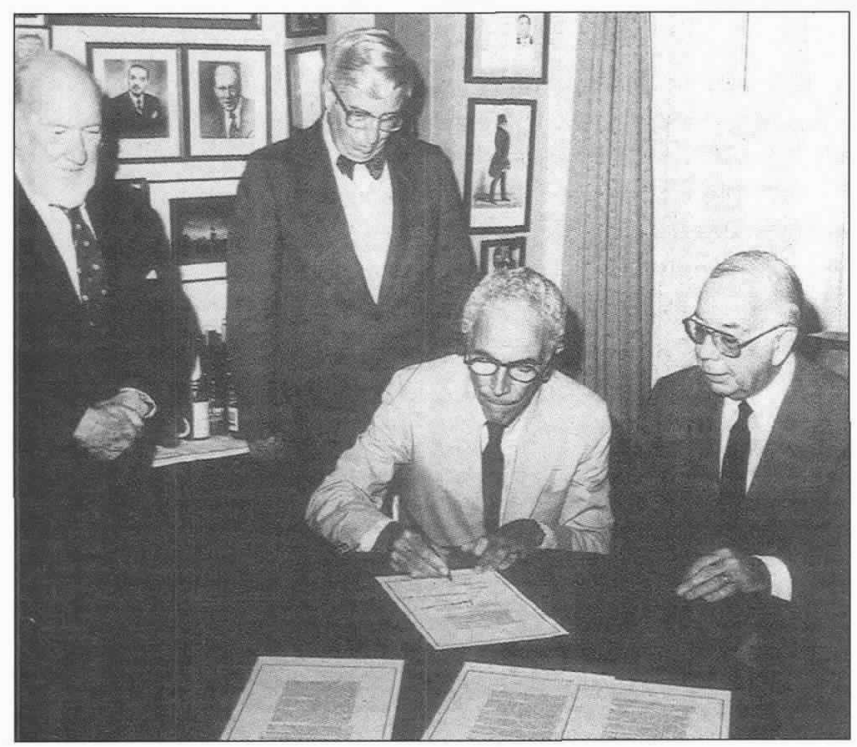

John Knauss, joined by Athelstan Spilhaus (left), Senator Claiborne Pell (signing) and Congressman Paul Rogers (right) at 20th Anniversary celebration for the Sea Grant Program, 1986.

board of the Ford Foundation and former president of MIT; the commission became known as the Stratton Commission. John Knauss was one of the 15 members of the commission appointed by President Johnson, along with Robert White (Administrator of the Department of Commerce Environmental Science Services Administration), Charles Baird (Under Secretary of the Navy), Jacob Blaustein (founder and President of Standard Oil of Indiana), George Reedy (President Johnson's press secretary), and Leon Jaworski (a friend of President Johnson who later became the President of the American Bar Association and the independent prosecutor in the Watergate investiga-
A key concession that Knauss successfully helped to negotiate was the right to do research on continental margin areas that extended beyond the 200 mile limit.
John Knauss' strong advocacy for freedom of research on the high seas resulted in his participation in the Law of the Sea discussions and negotiations. He was appointed to a public advisory committee to the Law of the Sea delegation to represent the ocean science community point of view. His conscientious work on the public advisory committee led to his appointment as a delegate for the U.S. negotiating team. Before the negotiations, he spoke to colleagues about freedom to do research on the high seas, but once the talks began, he soon realized that the biggest battle was to ensure the right to do research within the 200 mile limit of the Exclusive Economic Zone (EEZ). He was joined by Paul Fye of Woods Hole Oceanographic Institution in raising the importance of this issue to the oceanographic community.

According to Lewis Alexander, who was the Geographer of the State Department working with Knauss on this issue (Alexander had also been a Deputy Director of Staff for the Stratton Commission), the U.S. started to think of concessions to give to coastal states in order to provide the right to freedom of research in the EEZ. When it looked like we would not be able to preserve the freedom of research in the EEZ, the coastal states argued for the concessions that had been mentioned. According to Alexander, "The Russians played a key role. We thought that we had convinced them to go along with freedom of research within the 200 mile limit, but they reversed their position during the negotiation. It took the heart out of the U.S. team" (Alexander, 2001). A key concession that Knauss successfully helped to negotiate was the right to do research on continental margin areas that extended beyond the 200 mile limit. Coastal states had made strong arguments that continental margin were a tion). Other members are listed in the article by Merrell et al. in this issue.

Knauss was the only academic oceanographer on the commission. The report of the commission (Our Nation and the Sea: A Plan for National Action, 1969) included more than 100 recommendations, including one which led to the October 3, 1970 creation of the National Oceanic and Atmospheric Administration by President Nixon. White led this new agency as the first administrator and Knauss later led as Undersecretary of Commerce for Oceans and Atmosphere under the George Bush Sr. administration.

Other important actions that resulted from the Stratton Commission report included the formation of the Coastal Zone Management Act. Knauss (1990) points out that UNOLS was formed as an alternative to the National Laboratories proposed by the commission (see article by Bash in this issue). part of the continent and that even if they extended beyond the 200 mile limit of the EEZ, they should be considered part of the EEZ of the adjoining nations and that access should be controlled. His success with this issue allows access to many important parts of the continental margins outside of the EEZ (see article by Juda in this issue).

\section{Marine programs at URI}

During the Law of the Sea negotiations, Alexander and Knauss began to discuss the importance of geographic research in marine science issues. Alexander was associated with the University of Rhode Island's Geography department, which already had faculty interested in geography related to marine and coastal affairs. When Alexander returned from his detail to the State Department, Knauss and Alexander proposed to 
the University that the department become the Department of Geography and Marine Affairs. That department offered the first marine affairs degree in the U.S. With time, marine concerns became the hallmark of the department and Knauss and Alexander proposed that it focus exclusively on marine affairs. John felt that study of marine affairs was an essential foundation, together with marine science, for informed decisionmaking. He fostered the development of the department and, with time, it offered the first Ph.D. in marine affairs in the U.S. After John retired from NOAA, he returned to URI as an emeritus faculty member but taught in the marine affairs department.

John's vision of a university in which marine themes were important in many departments resulted in the development of the country's first Ocean Engineering Department, a Resource Economics department with great strength in marine resource economics, and an emphasis on problems of the coastal zone that distinguished its Civil and Environmental Engineering Department, Natural Resources Science Department and in the evolution of Animal Sciences into Fisheries, Aquaculture and Veterinary Sciences. Marine related studies flourished in the arts and humanities as well as the sciences. In recognition of the role that he played in making this happen, Knauss was made a Vice President of Marine Affairs at the University by President Frank Newman.

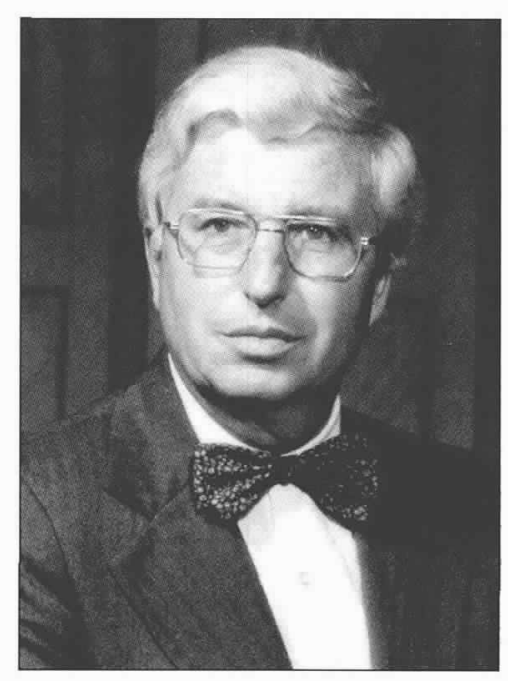

\section{He had likened John}

to the movie character, Forrest Gumpcertainly not in intelligence, but for his uncanny ability to be a part of nearly every major development in oceanography of the last 50 years. ty. Newman says that the Board of Governors for Higher Education asked him what he was going to get control of Knauss. He responded that he was going to make him a Vice President. And he did.

After stepping down as Dean and Vice President at the University of Rhode Island, he was recruited by the George Bush Sr. administration to become the administrator of NOAA. One of my favorite photos of John was taken immediately following his confirmation hearing in the Senate. He is flanked by Senator Claiborne Pell and Senator John Chafee, two major forces in marine and environmental legislation. Unknown to most, under his crisp white shirt and, of course, the signature bow tie, was a grungy Graduate School of Oceanography T-shirt, which had been auctioned off to high bidders annually at a benefit auction if they felt that they could add to its pedigree (the auction tradition had been started when Rhode Island's junior Congresswoman, Claudine Schneider, had worn it to a dinner with headhunters in New Guinea). The bow tie was such a symbol of John that when he left URI for NOAA, the attendees at a party in his honor all wore bow ties - men and women alike. A memorial quilt, made for the 25th anniversary of the founding of GSO, has a quilted appliqué of the building that houses the Dean's office. The appliqué is quilted in bow ties.

Recently the University of Rhode Island sponsored a symposium in honor of John's 75th birthday. I was asked to make comments at the end of the symposium and before the dedication of the main quadrangle of the campus in his name. Ken Brink, Chair of the Ocean Studies Board of the National Academy of Sciences, previous president of The Oceanography Society, and guest editor of this issue, had talked with me the previous week. He had likened John to the movie character, Forrest Gump-certainly not in intelligence, but for his uncanny ability to be a part of nearly every major development in oceanography of the last 50 years. An even more important characteristic of Forrest Gump, and one that I always associate with John, is the grace and character to bring out the best in all those who work with him.

\section{JOHN, WE SALUTE YOU!}

\section{ACKNOWLEDGEMENTS}

I would like to thank a great many people who spoke with me in the past and for this article about John Knauss and provided their perspectives on John's career, especially, Jim Baker, Lew Alexander, Ken Brink, Walter Gray, Sara Hickox, Frank Newman, Scott Nixon, Ned Ostenso, Senator and Mrs. Claiborne Pell, Fred Saalfeld. 


\section{REFERENCES}

Alexander, L., 2001: oral communication.

Difford, W., ed., 1965: Proceedings of the conference on the concept of a Sea-Grant University. Univ. of Rhode Island, 96pp.

Duce, R.A., 2001: GSO and John Knauss. Oceanography, this issue.

Farrington, J.W., 2001: Sverdrup, Johnson, and Fleming's The Oceans Revisited: What of the Future of Graduate Education in Ocean Sciences? Oceanography, this issue.

Inman, D., 2000: Reflections on oceanography at Scripps at the end of World War II, Oceanography. In: The
Making of a Science-People, Institutions and Discovery. Office of Naval Research, La Jolla, CA.

Knauss, J.A., 1990: The Stratton Commission-Its history and its legacy. Oceanography, 3(1), 53-55.

Lill, G., A. Maxwell and F. Jennings, 1959: The Next Ten Years in Oceanography. Office of Naval Research Technical Report.

Miloy, J., 1983: Creating the College of the Sea: the Origin of the Sea Grant Program. Texas A\&M University Sea Grant College Program, TAMU-SG-83-604, 64 pp.

Saalfeld, F., 2001, written communication.

Weisberg, R.H., 2001: An Observer's View of the Equatorial Ocean Currents. Oceanography, this issue.

\section{The South Seas, the Indian Ocean, and the 1997-1998 El Niño: Influences of John Knauss}

\begin{abstract}
1W hile walking back to my graduate student lodgings on a snowy winter day in Ithaca, New York, I learned from my roommate that his brother had a fellowship from Scripps to go to the South Seas for the summer. This sounded good to me, so I wrote and was accepted. When I arrived in La Jolla, I was told that I would work for a 35-year old graduate student, John Knauss, and instead of the South Seas, we would just be going south of San Diego. But it seemed like fun anyway, and I made the Dorado cruise aboard the R/V Horizon, a 150-foot seagoing tug.

Dorado had all the elements of an oceanographic venture: I was seasick and listened to the rumors that we would land in Manzanillo and could take the bus home (not true!); the seas were so high that all the fish in the aquarium died; and one night while we were sitting out on the fantail, I saw all the stars disappear on one side: it was a giant wave that had blocked them out. But we all survived, and the one picture that I truly remember is John sitting in the lab with a big globe planning his next expedition. This seemed irresistible: doing science and being an explorer.

I asked John how to became an oceanographer; he said finish your degree and write to me. By then, he had taken a new job as Dean of the Graduate School of Oceanography at the University of Rhode Island, and I became his first post-doc. We met in Singapore and spent six months working with Bruce Taft studying the currents in the equatorial Indian Ocean, as part of the International Indian Ocean Expedition. John's work with Bruce was important there because it showed how the equatorial undercurrent was stable in one direction, unstable in the other-an unexpected result, and one
\end{abstract}

that helped lay the groundwork for the theoretical understanding of the equatorial current system.

John and I overlapped again at Joint Oceanographic Institutions in Washington when I was President and he was a member of the Board of Governors. We talked frequently while he was my predecessor as Administrator of the National Oceanic and Atmospheric Administration (NOAA). One of the topics he focused on at NOAA was the development of an observation and modeling capability for El Niño under John, the TOGA TAO array was perfected and maintained, and he started the process for the joint university/government enterprise called the International Research Institute, now housed at Columbia University on the Lamont-Doherty Earth Observatory Campus in a new building.

By the time the largest El Niño of the century started in 1997, thanks to what John had supported, we were well prepared to monitor its evolution. Unlike the El Niño of 1982-1983, which was well underway before anyone was really aware, the 1997-1998 event was carefully tracked and continual forecasts of El Niño-related weather were provided globally.

I am grateful to Scripps and to John for starting me on my oceanographic career, and introducing me to so many people who have become lifelong friends. As with many famous oceanographers of the past, John's mentoring as well as his accomplishments have been an important part of the development of the field of oceanography.

D. James Baker Washington, DC USA 